\title{
Principal caregivers of oncology patients in palliative care and their perspectives on death
}

\author{
Guimarães $\mathrm{CA}^{1}$ and Marilda E Novaes Lipp ${ }^{2 *}$ \\ ${ }^{1}$ Universidade de Uberaba, MinasGerais, Brazil \\ ${ }^{2}$ Instituto de Psicologia e Controle do Stress, São Paulo, Brazil
}

\begin{abstract}
The overall aim of this study was to ascertain how the principal caregivers of oncology patients placed under Palliative Care envision the act of caring and the imminent loss of a family member, evaluating how this affects their levels of emotional stress. Ten caregivers aged between 31 and 73 , who were also family members, participated in the study, $80 \%$ of the sample being female. Oncology patients, accompanied by their respective caregivers, were cared for at a hospital in upstate São Paulo. For the data collection, a semi-structured interview script and Lipp's Stress Symptoms Inventory (LSSI) for adults were used. Data analysis was both quantitative and qualitative. The results showed that $100 \%$ of the respondents suffered from stress, of which $60 \%$ were in the near-exhaustion phase and $40 \%$ in the resistance phase. It was found that the act of caring is envisioned by caregivers as bringing about change, both in daily routines and in interpersonal family relations, that create difficulties, necessities and growth during the terminal stages of the patient's life. Caregivers' experiences of the imminence of the death of a loved one gave rise to assorted feelings, such as fear, despair, impotence, thinking about one's own finiteness and the avoidance of thoughts of death. It is important to emphasize that, despite the small sample size of the study, the results are consistent with other studies, underscoring the need to devise specific, effective and continuous interventions with the principal caregivers of patients with no hope of a cure, for the good of their own health, improvement in the quality of life and preparation for potential loss and separation.
\end{abstract}

\section{Introduction}

The role of the principal caregiver, usually a family member, in addition to the practical care, involves the taking of decisions about the treatment, as well as family, occupational and other issues. This can generate a high level of stress and overload. This situation may be aggravated when the patient's prognosis reveals there is no longer any chance of a therapeutic cure and the death of the loved one is nigh.

The aim of this study was to ascertain how the principal caregivers of oncology patients placed under Palliative Care envision the act of caring and the imminent loss of a loved one, evaluating how this affects their level of emotional stress. The underlying premise is that the family is one of the constituents of care in the process of the disease.

When disease is present, it spreads suffering and sometimes destroys the most basic fabric of life. Alleviating this human suffering must be understood as an essential element of caring [1]. Diseases such as cancer that are life-threatening, generate stress, not only for the patients but also the families, even when the treatment is successful, as the threat of recurrence remains. Fear of cancer is great. Many people know it is a disease that can be intensely painful and lead to invalidity, disfigurement or death [2].

Despite the diminished risk of the different forms of cancer, mortality rates in general climbed constantly over the course of the $20^{\text {th }}$ century [2]. It is estimated that for 2018 and 2019, in Brazil, 600,000 new cases of cancer will be reported, each year [3].

The turmoil that the impact of the disease causes may be more intense for the family than for the patients themselves, triggering stress, that may be accompanied by a variety of emotions, such as despair, irritation, intolerance and the recognition of the threat of loss that the patients' death may produce. All these reactions act at both the psychological and physical level of the individuals involved [4]. Stress is understood to be a complex response of the organism, where physical, psychological, mental and hormonal reactions are present when faced with any situation that is interpreted by the individual as daunting [5].

The increase in the possibility of treatment seeks to establish welfare measures that aim to reduce the impact of the disease and the respective treatments, providing the patient with better conditions of qualitative survival [6]. However, when it is confirmed that the disease is irreversible, and the patient has no prospects of a therapeutic cure, or control over the infirmity, the focus is not on cure but rather it is recognized that much still has to be done, both for the patient and the family, and it is in this context that the work of Palliative Care is placed.

Palliative Care emerges as an approach that aims to promote quality of life for individuals coping with life-limiting diseases, as well as the families, by means of clear, well-defined principles. So, Palliative Care has as its prerogative the "philosophy of caring", according to which death is part of a natural process in any individual's life course. Given this perspective, it is sought to care for the patient and the family, taking into account emotional, spiritual and social aspects [7-9].

Despite the negation and avoidance of the word death based on the citation in the WHO's definition of Palliative Care - "with life-

*Correspondence to: Marilda E Novaes Lipp, Instituto de Psicologia e Controle do Stress, São Paulo, Brazil, Tel: 551932340288, E-mail: mlipp@estresse.com.br

Key words: stress, cancer, principal caregiver

Received: February 04, 2019; Accepted: March 19, 2019; Published: March 22, 2019 
threatening diseases" -, the signification is that Palliative Care is more than just treating the symptoms, as the emphasis is placed on the quality of life, prevention and relief from physical, psychosocial and/ or spiritual suffering [10]. The fundamental proposition of Palliative Care is to facilitate comfort, warmth and protection, thereby providing a feeling of security for all those involved, both patient and family [11].

One of the items in the Palliative Care philosophy is the support which must be offered to the patient's family. The myriad of emotions experienced by patients and their families before death is something to which attention should be paid. Everyone will feel a certain degree of impact from the disease and, consequently, emotional upheavals and many changes, and these changes will be more than just physical. They will be social, psychological and spiritual; therefore, the emotional needs have to be addressed by means of appropriate interventions [12].

Cancer, just like any serious disease, awakens in the patient and family alike the imminence of death, which produces big changes in routine and expectations. Emotional reactions, changes in the existential dynamic, and in their beliefs, will be determined by the way individuals interpret and envision the situation [13].

A myth exists about suffering at the moment of death. It is believed that the process of death is followed by unbearable pain and suffering. This makes people retreat from gravely ill patients, due to the fear of "becoming infected" with the suffering and a feeling of impotence because they are unable to do anything to help. When it is possible to work with the family, with the principal caregiver, prior to the death event, the communication, the possibility of loss and separation, the process of bereavement and its preparation after death, are made easier [11].

\section{Method}

This was a qualitative and quantitative, cross-sectional study which allows for data collection in a natural setting in which the participants are experiencing the issue raised by the present study [14].

Taking part in the study were ten caregivers of oncology patients with a Palliative Care prognosis, cared for in a public hospital of a city in upstate São Paulo. The sample comprised 8 women and 2 men, aged between 31 and 73 .

The instruments employed were the Free and Informed Consent Agreement, Lipp's Stress Symptoms Inventory (LSSI) for adults, and an interview script put together specifically for this study [15]. The process was entirely based on the ethical parameters espoused by Brazilian National Health Council resolution 196/96 and the December 2000 criteria prescribed by the Federal Psychology Council (CFP). The project was approved by the Research Ethics Committee at the Mário Gatti Municipal Hospital (Project: 014/10).

\section{Results}

The study sample comprised 10 caregivers, $80 \%$ of whom were women and $20 \%$ men, aged between 31 and 73 . As far as marital status is concerned, $90 \%$ of the sample were married and $10 \%$ were separated. In terms of schooling, $40 \%$ of the sample had incomplete elementary education, $30 \%$ completed secondary education and $10 \%$ had concluded a technical course.

From the results of the LSSI, it was found that $100 \%$ of individuals in the sample suffered from stress, of whom $60 \%$ were in the nearexhaustion phase and $40 \%$ in the resistance phase. It was found that $90 \%$ of caregivers presented with predominantly psychological symptoms, but also with a significant percentage of physical symptoms.

For the analysis of the semi-structured interview script, the responses obtained were analyzed in accordance with the objectives of the study, based on the categories established in the analysis of content [16].

In terms of the assessment of what it meant for the caregiver to have a family member in Palliative Care, the following categories were abstracted: Imminence of death; Technical understanding versus Practical knowledge and Special caring.

It was possible to recognize that, for half of the sample (50\%), having a family member in Palliative Care represents the proximity of death. Of these respondents, 30\% would not utter the word "death" and so one can see the reluctance of the participants to pronounce it. However, in their responses, the relationship between Palliative Care and imminence of death is present, albeit implicitly, as evidenced by the following statement of one of the participants, C06: "It's hard! There are no words, I can't express what it is, it's a great pain, I'm afraid if I talk about it, it is going to happen".

The other $20 \%$ demonstrated, explicitly, the relationship between Palliative Care and death, as can be seen in the following response by C05: "It's hard, you end up counting down the days. [...] It seems that life is hanging by a thread, that we're near the end".

In the first case described above, the way in which death can be presented is also a reluctance, which can generate immense anxiety in the caregiver. In the words of caregiver C05, death may happen at any moment, one senses the recognition of our finiteness, a situation that may generate a state of constant alert in the caregiver.

Another important aspect that should be highlighted is that $30 \%$ of respondents said they were unaware of the term Palliative Care, but they demonstrated through their words that they are providing this care to the patients, in other words there is experience of the practice which satisfies one of the essential principles of Palliative Care, which depends on the caregivers' effort and commitment. As typified by the response of participant C01: "I don't know what palliative means, but it is caring for her 24 hours a day";

For some caregivers, having a family member in Palliative Care means supplying constant, special care, such as that offered by the hospital. An example of this category can be seen in the words of caregiver C10: "I ask God to come to the hospital, care is different here".

In the question related to death, it was found that $80 \%$ of respondents stated they thought of death, and the other $20 \%$ said they did not. It was observed that $80 \%$ of caregivers, explicitly or implicitly, thought of death in this context. Two of them said they thought about the death of the patient, but the underlying fear was about their own death, as in the case of caregiver C02, who said: "I am afraid of cancer, I am terrified. Damn disease, he (the patient) is watching his own face being eaten away".

In the words of some caregivers, it was possible to note their difficulty in coming to terms with the loss and the possible separation from the other person. This can be seen in the words of caregiver C01: "I don't know what I'm going to do without her. [...] I wish I could go first".

The other $20 \%$ of respondents said they did not think about death, though they may be using strategies to shield themselves, as the intense suffering present in this situation may cause an individual to avoid 
thinking and talking about this reality. The majority of individuals frequently use avoidance, primarily to relieve their anxiety, or when they come up against difficult life choices or situations [17].

\section{Discussion}

The principal caregivers in the process of any disease, in this case cancer, are extremely important for the care, both for the patient and for the team of professionals caring for the oncology patient since, for this group, they are the intermediaries who, for the most part, will be monitoring and/or adhering to the therapeutic plan for the individual being cared for. It would be unacceptable to suggest that caring has predetermined characteristics, as each case experienced is unique, singular, specific in this context. What can be seen, however, is that there are common characteristics with caring and it is this that has been presented in this study

It was possible to see that the care offered by the principal caregiver is charged with values, beliefs, family stories, bonds that have been constructed over the course of the lives of these protagonists (patient and caregiver). In the vast majority of cases, this was the decisive factor in the caregivers' definition, action and experience with the act of caring as well as their posture when faced with the imminence of the death of a loved one.

For the majority of caregivers, the situation of progression and deterioration of the disease, and with a prognosis that renders impossible a cure for the patients, generated feelings of impotence and despair, but also of hope. It was possible to see, in the results presented, that half of these principal caregivers associated Palliative Care with death, and here one may reflect on how much the proposition and principals of Palliative Care are still not part of the general understanding. While it is true that the prognosis is reserved, this does not mean it is the end. There is still much to do to prevent unnecessary suffering. Despite some of the caregivers not being familiar with the term "Palliative Care", nor its proposition or significance, it was possible to see that the majority of them practice its precepts, seeing that they strive to satisfy the needs and wishes of the patient, and find ways to alleviate their suffering.

Cancer is a disease that carries the stigma of death, which, in the advanced stages of the disease, becomes more and more evident, creating myriad emotions in the patient and caregiver. Death is a difficult subject to be addressed among the caregivers, some of whom, during the interviews, would not even articulate the word "death". It was also possible to observe the presence of a maelstrom of feelings, sadness, uncertainty, anxiety, some of them ambiguous, generating guilt because, on the one hand, if the caregiver wishes for the suffering of the other to be relieved by death, at the same time he/she feels guilty for having these thoughts.

Resisting death may create the idea of strength and control, however, when life has run its course, without it being possible to prepare for bereavement, there is no allowance on the part of others or even of ourselves, for the expression of sadness, pain, which can generate grave consequences, including falling sick [18].

\section{Closing remarks}

It was possible to ascertain that the individuality of the act of caring characterizes the emotional experience that caregivers have when they dedicate themselves to the patients under their care, since the patient, caregiver and family are unique, and within this peculiarity are involved experiences, stories, beliefs and values that have been constructed over the course of these people's lives.

In this context, it was possible to observe that the disease, imminence of death and the process of dying create uncertainties about life, fear of death, increased levels of stress; feelings of sadness, despair and guilt; personal growth; reflections that are conducive to change and reflections about ourselves, about our neighbor, about the world. However, it is believed that when all those involved in these circumstances have the possibility of affective, family, social, spiritual and professional aid/support, the journey along this path can be more comfortable.

For this to happen, it is necessary to have the involvement of a multi-professional team with an interdisciplinary vision, i.e. a holistic approach in which human beings are viewed in a biopsychosocial and spiritual way, so that together they can decide on adequate, achievable strategies for each case. Here, the role of the psychologist should be underlined as, a priori, in this situation, he/she possesses a variety of functions towards the patient, family, principal caregiver and the team.

In the present study, the emphasis was on the principal caregiver and, as it unfolded, the importance of the role of the caregivers in caring was ascertained and also how much they also need to receive care, so that they can exercise their function in an adequate, balanced way, so they can be certain they have done all they can, preparing for the death of their loved one and the preparation for bereavement, from their own resources, to get over the pain of loss and separation.

Therefore, it is hugely important that this caregiver, as well as the patient, gets continuous, professional monitoring, ranging from communication of the diagnosis; during treatment, after treatment when a cure has become possible; when the prognosis indicates the impossibility of a cure, during the journey which is the process of dying and subsequent to the death of the patient.

\section{References}

1. Barros TM (2003) Psicologia e Saúde: Intervenção em Hospital Geral. In: R. M. Caminha, R. Wainer, M. Oliveira \& N. M. Piccoloto. (Org). Psicoterapias cognitivocomportamentais: teoria e prática. (pp. 239-245). São Paulo: Casa do Psicólogo.

2. Straub R O (2005) Psicologia da saúde (R. C. Costa, Trad.) Porto Alegre RS: Artmed.

3. Instituto Nacional de Câncer José Alencar Gomes da Silva. Estimativa 2014 Incidência de Câncer no Brasil. Disponível.

4. Silva C N (2000) Como o câncer (des)estrutura a família. São Paulo: Annablume.

5. Lipp MEN, Malagris LEN (2001) O stress emocional e seu tratamento. In: B. Rangé (Org.). Psicoterapias cognitivo-comportamentais: um diálogo com a psiquiatria. (pp. 475-490). Porto Alegre, RS: Artmed Editora.

6. Souza CB (2003) O ser e o estar na doença oncológica. In: V. B. Oliveira, \& K Yamamoto. Psicologia da saúde: temas de reflexão e prática. (pp. 171-185). São Bernardo, SP: UMESP.

7. Crespo SMAC (2009) Histórias de vida e a doença oncológica terminal. Dissertação (Mestrado em oncologia) - Instituto de Ciências Biomédicas Abel Salazar do Porto, Universidade do Porto, Porto.

8. Silva RCF, Hortale VA (2006) Cuidados paliativos oncológicos: elementos para o debate de diretrizes nesta área. Cadernos de Saúde Pública, v. 22, n. 10, p. 2055-2066.

9. Moreira LM, Ferreira RA, Costa Junior AL (2012) Discussão de protocolo para cuidadores de pacientes com câncer em cuidados paliativos. Paidéia, v. 22, n. 53, p. 383-392.

10. Santos FS (2009) Cuidados Paliativos: discutindo a vida, a morte e o morrer. São Paulo: Editora Atheneu.

11. Kovács MJ (2003) Educação para a morte: temas e reflexões. São Paulo: Casa do Psicólogo. 
12. Fitch M (2006) Necessidades emocionais de pacientes e cuidadores em cuidados paliativos. In: C. A. M. Pimenta, D. D. C. F. Mota \& D. A. L. M. Cruz. Dor e cuidados paliativos - enfermagem, medicina e psicologia. (pp. 67-85). Barueri, SP: Manole.

13. Nucci NAG, Perina EM (2008) UTI de oncologia pediátrica: reflexões sobre o cuidado humanizado. In: E. Knobel, P. B. A. Andreoli, M. R. Erlichman. Psicologia e humanização: assistência aos pacientes graves. (pp. 281-290). São Paulo: Atheneu.

14. Creswell JW (2010) Projeto de pesquisa: método qualitativo, quantitativo e misto. 3. ed. Porto Alegre: Artmed.
15. Lipp MEN (2000) Inventário de sintomas para adultos de Lipp. São Paulo: Casa do Psicólogo.

16. Bardin L (2004) Análise de conteúdo. Lisboa: Edições 70.

17. Beck AT, Freeman A, Davis DD (2005) Terapia Cognitiva dos Transtornos da Personalidade. Porto Alegre: Artmed.

18. Kovács MJ (2009) Educação para a morte. In: F. S. Santos (Org.). Cuidados Paliativos discutindo a vida, a morte e o morrer. (pp. 45-58). São Paulo: Editora Atheneu.

Copyright: $@ 2019$ Guimarães CA. This is an open-access article distributed under the terms of the Creative Commons Attribution License, which permits unrestricted use, distribution, and reproduction in any medium, provided the original author and source are credited. 